\title{
Tilalla tapahtuva maan laadun mittaaminen
}

\author{
Ansa Palojärvi ${ }^{1)}$, Laura Alakukku ${ }^{1)}$, Merja Myllys ${ }^{1)}$, Jaana Nikkilä ${ }^{2)}$ ja Kaisa Tolonen ${ }^{3)}$ \\ ${ }^{1)}$ MTT (Maa-ja elintarviketalouden tutkimuskeskus), 31600 Jokioinen, ansa.palojarvi@mtt.fi, \\ laura.alakukku@mtt.fi.merja.myllys@mtt.fi \\ 2)ProAgria Etelä-Savo, 50100 Mikkeli, jaana.nikkila@proagria.fi \\ ${ }^{3)}$ ProAgria Maaseutukeskusten Liitto,01301Vantaa,kaisa.tolonen@proagria.fi
}

Kaikelle peltoviljelylle on tärkeää, että huolehditaan maan hyvästä rakenteesta, kasvien luontaisesta ravinteiden saannista, maan vesitaloudesta ja vältetään ympäröivien ekosysteemien kuormittamista. Maan hyvä kunto pitää sisällään useita eri tekijöitä. Kemialliset tekijät kuvaavat maan ravinnetilaa, eloperäistä ainesta ja happamuutta. Fysikaaliset tekijät ovat keskeisiä maan rakenteelle, vesitaloudelle ja eroosioriskille. Biologiset tekijät taas vaikuttavat luontaiseen ravinteidensaantiin vapauttamalla ravinteita eloperäisestä aineksesta tai symbioosissa viljelykasvin kanssa sekä ovat mukana maan rakenteen muodostuksessa ja ylläpitämisessä synnyttämällä humusta, sitomalla pintamaan muruja ja luomalla ns. biohuokosia. Kun näihin liitetään kestävän maatalouden ajatus, voidaan puhua maan laadusta.

Monipuolista mittaristoa maan laadun arvioimiseksi ja kehityksen seuraamiseksi tiloilla ei meillä ole toistaiseksi ollut tarjolla. Kansainvälisesti jo useita maan laadun mittaristoja on olemassa ja meilläkin tarve peltomaan biologisten ja fysikaalisten ominaisuuksien arvioimiseen viljavuustutkimuksen täydentäjänä on ilmeinen. Mittaristokokonaisuuden kehitystyössä voidaan hyödyntää ulkomaisia esimerkkejä, mutta käyttöönotto vaatii soveltamista ja testaamista paikallisissa olosuhteissa.

Hankkeen päätavoitteena oli kehittää neuvoja- ja viljelijäkäyttöön soveltuva mittarikokoelma maan laadun monipuolista arviointia varten. Mittaristo sisältää testejä maan biologisista, kemiallisista ja fysikaalisista ominaisuuksista. Hankkeen kuluessa ProAgria Maaseutukeskusten neuvojat eri puolella Suomea ovat testanneet mittarikokoelmaa. Käyttökokemusten perusteella testikokonaisuutta, ohjeistusta ja välineistöä on muokattu. Tulosten tulkintaa ja toimenpide-ehdotuksia varten tarvitaan taustatietoja tilan lohkojen luontaisista ominaisuuksista ja viljelytoimenpiteistä. Tiedot on mahdollista koota valtakunnallisesti ProAgrian Lohkotietopankin avulla, jolloin viljelijöiden on mahdollista vertailla oman tilansa tuloksia. Lohkotietopankkiin kertyviä tuloksia voidaan myös jatkossa käyttää hyväksi suositusarvojen tarkentamisessa. Tavoitteena on, että oman tilan peltojen kunnon seuraaminen ja arvojen vertailu motivoisi viljelijöitä muutoksiin. Maan laadun mittaamista voidaan soveltaa myös veisensuojelutyössä maaperästä aiheutuvien riskien arvioimiseksi ja paikantamiseksi, sekä viljelymuutosten vaikutusten seurantaan.

Hanke loppuu vuoden 2005 lopussa, jonka jälkeen valmistuu mittarikokoelman käyttöä varten laadittu CD-rom -muotoinen tukimateriaali, mikä tullaan julkaisemaan myös uudistuvan Agronetin sivustoilla.

\section{Kirjallisuus}

Kukkonen, S., Alakukku, L., Myllys, M., \& Palojärvi, A. 2004. Maan laadun arviointi tiloilla - kirjallisuuskatsaus. Maa- ja elintarviketalous 63: 86 s. http://www.mtt.fi/met/pdf/met63.pdf Verkkojulkaisu päivitetty 10.12.2004.

Palojärvi, A. \& Nuutinen, V. 2002. The soil quality concept and its importance in the study of Finnish arable soils. Agricultural and Food Science in Finland 11: 329-342. 